\title{
Sinergasilus polycolpus, a new copepod species in the ichthyoparasitofauna of Serbia and Montenegro
}

\author{
P. Cakic*, M. Lenhardt, J. Kolarevic
}

Institute for Biological Research ‘Sinisa Stankovic', 29 Novembra 142, 11000 Belgrade, Serbia and Montenegro

\begin{abstract}
The parasitic copepod Sinergasilus polycolpus was identified on the gills of bighead carp Aristichthys nobilis from 2 localities (Kladovo and Slankamen) in the Serbian part of the River Danube. This parasite is species-specific for 2 Chinese carp, the bighead carp and the silver carp Hypophthalmichthys molitrix. It was accidentally introduced into Serbia and Montenegro together with fry of these herbivorous carp intended for aquaculture and control of phytoplankton blooms. There is no record in the available literature of this parasite for European freshwaters. Our identification of $S$. polycolpus signals the possible spread of the infectious disease sinergasilosis in natural freshwaters and in fishponds, similar to bothriocephalosis, caused by Bothriocephalus opsariichthydis, which was introduced with the fry of various herbivorous species from the Amour River basin (USSR) into almost all countries throughout the world.
\end{abstract}

KEY WORDS: Parasitic copepod · Sinergasilus polycolpus · First record · Serbia · Montenegro

Both bighead carp Aristichthys nobilis Richardson and silver carp Hypophthalmichthys molitrix Valenciennes were introduced to Serbia and Montenegro in 1963 from Romania, Hungary and the former USSR (Welcomme 1988), for aquaculture purposes. Although they do not normally breed outside their native rivers, acclimatized populations of these fishes have appeared in the River Danube and become members of its native fauna.

During a study of fish parasites in the Serbian section of the River Danube and in some fish ponds between 1995 and 1997, a new copepod was detected on the gills of bighead carp that differed from other parasitic copepods found in Serbian waters.

Aristichthys nobilis were caught downstream of Kladovo, near Mala Vrbica $(\mathrm{km} 927$ of the River Danube), in summer 1995, and near Slankamen $(\mathrm{km}$ 1216 of the River Danube) in summer 1997. All fish were caught by net and thoroughly examined by standard parasitological methods. All parasites found were fixed, and semi-permanent and permanent slides prepared.
Examination of morphometric and other biological features of both fresh and preserved parasites, based on the classifications of Byhovskaya-Pavlovskaya et al. (1962), Bauer et al. (1981) and Bauer (1987), initially identified a species of parasitic copepod new to Serbian waters as Sinergasilus lieni. However, these classifications proved to be out of date insofar as they did not recognize that $S$. lieni is not a valid taxon, but a junior synonym of $S$. polycolpus Yin, described by Yin in 1949 (Yin 1949), later corrected by the same author, and subsequently confirmed by Kuang \& Qian (1991). Taking this into account, we therefore re-identified the new ichthyoparasite as Sinergasilus polycolpus.

Gills of fish infected by Sinergasilus polycolpus were altered. On the exact spot where a copepod was found gills were swollen and milky white, with 2 to 3 neighbouring gill lamellae glued together. Considering the number of fish examined and the number of parasites detected (Table 1), we conclude that infestation was low and did not pose a threat to fish fauna. 
Table 1. Sinergasilus polycolpus on gills of bigheaded carp Aristichthys nobilis from River Danube, showing no. of fish examined, their length, weight, and no. infected, no. of parasites found, and \% infestation

\begin{tabular}{|c|c|c|c|c|c|c|c|}
\hline Locality & $\begin{array}{c}\text { Sampling } \\
\text { date }\end{array}$ & $\begin{array}{l}\text { No. of } \\
\text { fish }\end{array}$ & $\begin{array}{l}\text { Length } \\
\text { (cm) }\end{array}$ & $\begin{array}{c}\text { Weight } \\
\text { (g) }\end{array}$ & $\begin{array}{c}\text { No. } \\
\text { infected }\end{array}$ & $\begin{array}{c}\text { No. of } \\
\text { parasites }\end{array}$ & $\begin{array}{c}\% \\
\text { infestation }\end{array}$ \\
\hline Mala Vrbica & July 1995 & 6 & $18-20$ & $50-180$ & 2 & 3 & 33 \\
\hline Mala Vrbica & August 1995 & 8 & $30-46$ & $800-1100$ & 1 & 7 & 12.5 \\
\hline Slankamen & July 1997 & 2 & $34.5 ; 93$ & $1200 ; 11000$ & 1 & 2 & 50 \\
\hline
\end{tabular}

This sole record of Sinergasilus polycolpus in Serbia and Montenegro indicates an extended distribution area of this species, and the possible spread of the infectious disease sinergasilosis into Serbian natural freshwaters and fishponds. As this parasite is considered to be one of the primary pathogens of bighead and silver carp (Wang et al. 2002), with a prevalence as high as $50 \%$ and high morbidity (Yulin 1996), we aim to intensify our future research on this species.

\section{LITERATURE CITED}

Bauer ON (1987) The guide for determination of parasites of freshwater fish, Vol 3. Akademiya Nauk SSSR, Leningrad Bauer ON, Musselius VA, Strelkov YA (1981) Diseases of fish kept in ponds. Legkaya i pishchevaya pomyshlennost,

Editorial responsibility: Wolfgang Körting,

Hannover, Germany

\section{Moscow}

Bykhovskaya-Pavlovskaya IE, Gusev AV, Dubinina MN, Izyumova NA and 5 others (1962) The guide for determination of parasites of fresh water fish of SSSR. Akademiya Nauk SSSR, Leningrad

Kuang PR, Qian JH (1991) Parasitic crustacea of freshwater fishes: economic fauna of China. Science Press, Beijing (in Chinese)

Wang GT, Wen XL, Yao WJ, Nie P (2002) Mortalities induced by the copepod Sinergasilus polycolpus in farmed silver and bighead carp in a reservoir. Dis Aquat Org 48:237-239

Welcomme RL (1988) International introduction of inland aquatic species. FAO Fish Tech Pap 294:128-132

Yin WY (1949) Three new species and a new genus of parasitic copepods (Ergasilidae) from China pond fish. Sinensia 20:32-42 (in Chinese with English abstract)

Yulin J (1996) A review of traditional and innovative aquaculture health management in the People's Republic of China. FAO Fish Tech Pap 360:88-103

Submitted: March 23, 2003; Accepted: December 4, 2003 Proofs received from author(s): February 12, 2004 